\title{
BELASKASIHAN MEMBEBASKAN DARI PENGHAKIMAN MENURUT YAKOBUS 2:13 DAN IMPLIKASINYA BAGI KEHIDUPAN ORANG PERCAYA MASA KINI
}

\author{
Meriana Zega, Yayan Indrawan \\ Sekolah Tinggi Teologi Soteria Purwokerto \\ Merryzega21@gmail.com
}

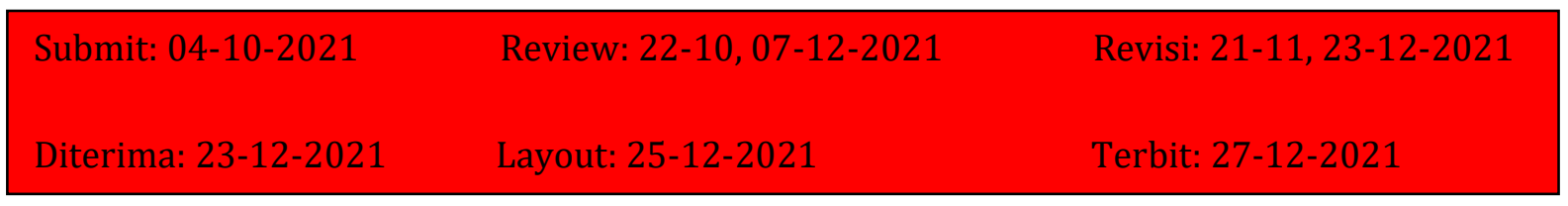

\begin{abstract}
Many believers think that mercy is only for those in need or all believers. For this reason, this study aims to provide an explanation of the mercy needed by every believer to free someone from judgment according to James 2:13. The method used is a text analysis approach, which focuses on the text itself and is compared with other book texts. The results of the study stated that based on James 2:13, mercy is the key to victory over judgment from God, channeling mercy is something that is continuously done without stopping. As a person who has received God's forgiveness and mercy, he should be able to forgive others without limits. Because this is not the law of burden but the law of love that every believer must respect and implement because the proof of mercy is to do God's law, which is to love God and love your neighbor as yourself, because at the time of judgment that person will be loved by God and free from judgment.
\end{abstract}

Keywords: Mercy, liberating, winning, judgment

\section{ABSTRAK}

Banyak orang percaya yang beranggapan bahwa belas kasihan hanyalah bagi mereka yang membutuhkan atau semua orang percaya. Untuk itu, penelitian ini bertujuan untuk memberi penjelasan tentang belas kasihan yang dibutuhkan oleh setiap orang percaya yang membebaskan seseorang dari penghakiman menurut Yakobus 2:13. Metode yang digunakan yaitu pendekatan analisis teks yaitu fokus pada teks itu sendiri dan dikomparasikan dengan teks kitab lainnya. Hasil penelitian menyatakan bahwa berdasarkan Yakobus 2:13, belas kasihan adalah kunci untuk menang atas penghakiman dari Allah, menyalurkan belas kasihan adalah sesuatu yang terus menerus dikerjakan tanpa henti. Sebagai orang yang telah menerima pengampunan dan belas kasihan Tuhan seharusnya dapat mengampuni sesama tanpa batas. Karena ini bukanlah hukum beban melainkan hukum kasih yang harus dihormati dan dilaksanakan oleh setiap orang percaya sebab bukti dari belas kasihan adalah melakukan hukum Allah, yaitu mengasihi Allah dan mengasihi sesama manusia seperti diri sendiri, karena pada waktu penghakiman orang itu akan dikasihi oleh Allah dan bebas dari penghakiman.

Kata Kunci: Belas kasihan, membebaskan, menang, penghakiman 


\section{Pendahuluan}

Setiap orang percaya kepada Kristus hidup sebagai orang yang telah menerima belas kasihan Tuhan. Akan tetapi dalam kehidupan tidak banyak yang menyalurkan belas kasihan yang mereka terima dari Tuhan kepada orang lain mereka beranggapan bahwa belas kasihan hanya untuk orang-orang yang membutuhkan. Seperti yang dialami masyarakat Afghanistan yang tidak memperoleh belas kasihan dari suku Taliban. Contohnya penjualan anak perempuan dari seorang bapak Mohhamad Ibrahim dari daerah Kabul. Dia terpaksa menjual anaknya untuk melunasi utang-utang keluarganya, Ibrahim tidak memiliki pilihan lain selain menjual anaknya karena apabila tidak menuruti maka rumahnya akan dibakar. ${ }^{1}$ Hal ini menunjukkan bahwa penting untuk memberikan belas kasihan kepada orang yang sangat terpuruk dan menderita. Banyak orang Kristen hidup tanpa menyadari bahwa mereka juga telah dimerdekakan dari dosa karena belas kasihan Tuhan.

Orang yang tidak memiliki belas kasihan adalah orang yang memiliki pikiran sempit dan orang yang belum sepenuhnya kenal dan percaya Kristus. Setiap orang yang tidak memiliki belas kasihan adalah orang yang tidak menerima belas kasihan dari Tuhan pada hari penghakiman. Matthew Henry menjelaskan bahwa orang yang sekarang ini tidak berbelas kasihan tidak akan dikasihani pada hari penghakiman. ${ }^{2}$ Sebab itu setiap orang Kristen perlu menyadari bahwa dirinya telah dimerdekakan oleh belas kasihan Tuhan karena sekalipun orang percaya di dunia sudah menerima pengampunan karena belas kasihan dari Tuhan, akan tetapi kehidupan orang percaya juga seharusnya mencerminkan sifat Allah dengan menunjukkan belas kasihan kepada semua orang tanpa memandang muka seperti Yesus Kristus.

William Dyrnes juga menekankan, karena di akhir zaman Tuhan akan mengirimkan belas kasihan-Nya di bumi, dan di mana pun Dia menemukan isi hati belas kasih, Dia tinggal di dalam dia. Karena pada tingkat di mana seseorang memiliki belas kasihan terhadap sesamanya, pada tingkat yang sama Tuhan juga memilikinya (1Kor 8: 3). ${ }^{3}$ Pernyataan tersebut menurut saya belum lengkap. Dengan demikian, kenyataan tersebut mendorong saya untuk membahas pentingnya belas kasihan karena membebaskan dari penghakiman, secara khusus saya akan menyoroti Yakobus 2:13 yang dibagi menjadi dua poin, yaitu: Pertama, penghakiman tanpa belas kasihan berlaku kepada orang yang tidak berbelas kasihan. Kedua, belas kasihan menang atas penghakiman.

\section{Metode Penelitian}

Metode yang digunakan adalah pendekatan analisis teks secara sintaksis dan semantis, yaitu fokus pada teks itu sendiri, interaksi dengan teks-teks lain dan tulisan para Bapa-bapa Gereja. Berikut beberapa unsur analisis teks secara sintaksis dan semantis yang dipakai dalam tulisan ini, yaitu: historia meneliti data teks tersebut yaitu

\footnotetext{
${ }^{1}$ Anak Perempuan Afghanistan Mulai Dijual Keluarga Demi Bertahan Hidup (detik.com)

2 Matthew Henry, Tafsiran Matthew Henry:Surat Ibrani, Yakobus, 1\&2 Petrus, 1-3 Yohanes, Yudas Dan Kitab Wahyu (Surabaya, 2016).

3 William Dyrnes, "'Mercy Triumphs Over Justice: James 2:13 and the Theology of Faith and Works The Gospel Coalition,' Accessed June 16, 2021, Https://Www.Thegospelcoalition.Org/Themelios/Article/Mercy-Triumphs-over-Justice-James-213-andthe-Theology-of-Faith-and-Works/."
} 
syntactic form dan terjemahan literal untuk menemukan poin-poin sintaksis. Selanjutnya syntactic point yang telah ditemukan akan dianalisis ke dalam semantic content (masuk dalam theoria atau menemukan makna spiritualnya). Kemudian, semantic point berisi uraian dari poin-poin yang telah didapatkan dalam semantic content dengan menginteraksikan dengan teks lain dalam Alkitab dan tulisan Bapa-bapa Gereja. Melalui itu semua orang akan mendapat outline concept yang berisi ringkasan dan rumusan konsep teologis yang dapat dibuat relevansinya berisi hal-hal yang dapat dikerjakan atau diaplikasikan oleh setiap orang percaya (personal).

\section{Hasil Dan Pembahasan}

\section{Historia: Data Teks, Syntactic Form}

Hasil penelitian kitab Yakobus 2:13 menggunakan syntactic form seperti skema bawah ini:

Ayat 13

$\gamma \grave{\alpha} \rho$

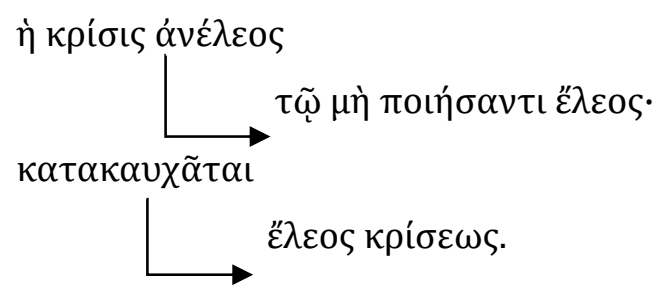

\section{Penjelasan Syntactic From}

Yakobus 2:13

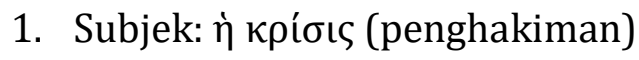

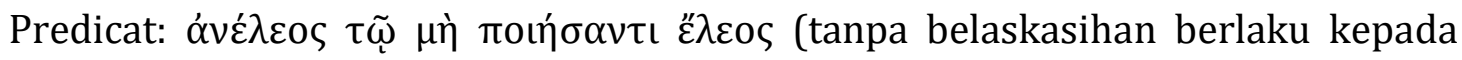
orang yang tidak berbelas kasihan).

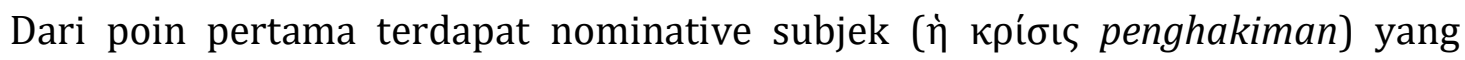

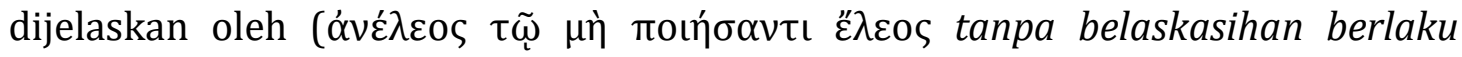
kepada orang yang tidak berbelas kasihan).

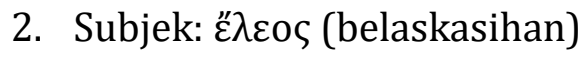

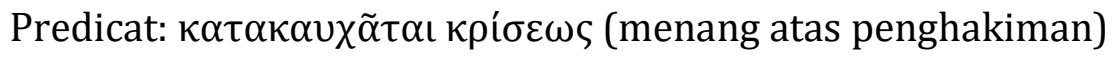


Poin kedua, عُ $\lambda \varepsilon o \varsigma$ (belas kasihan) menjelaskan bahwa belas kasihan lebih kuat

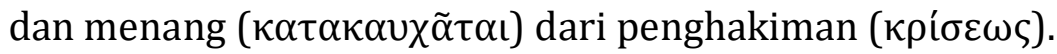

\section{Terjemahan Literal}

Karena penghakiman tanpa belas kasihan berlaku kepada orang yang tidak berbelas kasihan, belas kasihan menang atas penghakiman.

\section{Konteks Historis}

Secara keseluruhan dalam Yakobus 2:5-13 mengingatkan untuk berhenti memandang muka. Dalam ayat 5 dikatakan bahwa Allah memilih orang miskin untuk dijadikan kaya dalam iman, dan dijadikan ahli waris Kerajaan Surga (jadi kaya secara rohani, bukan secara jasmani). Ini tidak berarti bahwa Allah tidak menghendaki orang kaya. Ia memilih baik kaya maupun miskin karena memang dalam memilih, Ia hanya memilih berdasarkan kehendak-Nya sendiri. Kalau Allah seperti itu, lalu siapakah manusia sehingga dapat membeda-bedakan seseorang berdasarkan uang/kekayaan? Ini adalah sesuatu yang salah. Orang kaya sering menghujat nama Kristus pada waktu hamba-hamba mereka adalah orang Kristen mau menaati Kristus. Misalnya, dalam persoalan peraturan Sabat, jika hamba-hamba itu mau beristirahat sebagai wujud ketaatan di hari Sabat maka majikan mereka yang kaya itu akan memaki-maki mereka disertai hujatan kepada Kristus. Ini dipakai Yakobus sebagai argumentasi untuk menentang sikap memandang muka. ${ }^{4}$

Jadi, dalam konteks inilah Yakobus mengatakan bahwa orang kaya itu menghujat nama Kristus, tetapi kamu menghormati mereka. Sedangkan, orang-orang miskin itu tidak pernah menghujat nama Kristus, tetapi kamu menghina/mengabaikan mereka. Di ayat 9-11 dikatakan bahwa sikap membeda-bedakan orang dapat membuat seseorang melanggar hukum Tuhan karena dapat menyebabkan kita berbohong, berlaku tidak benar kepada orang lain. Jika telah melanggar satu bagian hukum ini, maka walaupun seseorang memelihara yang lain, tetap akan dinyatakan bersalah oleh Allah. Jadi, jika menyatakan belas kasihan kepada orang lain, maka akan mengalami penghakiman yang penuh dengan belas kasihan dari Allah (ayat 13b). Tetapi tidak menyatakan belas kasihan kepada orang lain maka akan mengalami penghakiman yang keras dari Allah (ay 13a).

\section{Theoria: Semantic Points (Penjelasan Ayat)}

\section{Karena Penghakiman Tanpa Belas Kasihan Berlaku Kepada Orang Yang Tidak Berbelas Kasihan.}

Secara tidak sadar sebagai orang percaya sering berpikir dan beranggapan bahwa belas kasihan untuk orang yang membutuhkan atau untuk semua orang percaya. Itu merupakan pemikiran yang dangkal. Yakobus menjelaskan penghakiman tanpa belas kasihan berlaku kepada orang yang tidak berbelas kasihan. Penghakiman merupakan hukuman Allah yang diberikan berdasarkan perbuatan (Rom. 2:1-16). N. T. Wright menjelaskan bahwa perbuatan itu adalah perbuatan yang mewakili keseluruhan hidup

4 “Churchofjesuschrist.Org." 
seseorang termasuk iman percaya kepada Tuhan. ${ }^{5}$ Oecumenius juga menegaskan bahwa memberi pengampunan terhadap dosa orang lain dan membalas yang baik kepada mereka dengan cara memberi apa yang diperlukan membuat belas kasih Tuhan membebaskan hidup ini dari penghakiman. Tetapi jika tidak memberikan pengampunan kepada orang lain hukuman yang setimpal akan ditunjukkan kepada kita seperti yang dinyatakan dalam doa Bapa kami (Mat 6:12). ${ }^{6}$ Dalam doa Bapa kami kita tidak hanya meminta pengampunan dari Tuhan, tetapi juga bersedia mengampuni sesama. Maka dari itu kita seharusnya mengampuni dosa orang lain supaya mendapat pengampunan dari Bapa dan mendapatkan belas kasih-Nya. Belas kasihan Tuhan membebaskan manusia dari penghukuman atas dosa. Oecumenius menyatakan dalam komentarinya bahwa belas kasihan Tuhan akan membebaskan dari penghakiman tapi jika tidak mengampuni maka Bapa tidak akan mengampuni. ${ }^{7}$ Pengampunan ialah melepaskan seseorang dari kesalahan memberi pengampunan bagi sesama sebagai bukti bahwa mereka telah menerima pengampunan dari Tuhan oleh belas kasihan-Nya. Menerima pengampunan berarti memberi pengampunan seperti Tuhan yang telah mengampuni tanpa batas. Jika tidak mengampuni maka akan menerima hukuman yang diberikan kepada hamba yang jahat bersama dengan pembalasan yang disebutkan dalam doa Bapa kami (Mat. 18:22).

Berbicara mengenai pengampunan, Asmat menyetujui bahwa pengampunan itu ialah pembebasan dari hukuman atau tuntutan. ${ }^{8}$ Dalam hal ini Asmat menyatakan bahwa pengampunan yang diberikan oleh Tuhan melepaskan seseorang dari kesalahan, mengampuni bukan sekadar ucapan tetapi tindakan yang memberi pengampunan sepenuh hati. Hidup saling mengampuni adalah salah satu bukti bahwa kita hidup dalam kasih Tuhan dan ikut terlibat dalam pekerjaan ilahi-Nya dengan memberi pengampunan tanpa batas.

Perbuatan yang mengampuni orang lain berlandaskan belas kasihan luput dari hukuman Allah tetapi perbuatan tanpa belas kasihan menerima hukuman tanpa belas kasihan dari Allah. Yakobus menambah peringatan ini dengan menekankan bahwa Allah akan menghakimi dan menghukum orang-orang yang tidak menunjukkan belas kasihan. Mengapa? Sebab ia menyamakan diri seperti Allah yang menghakimi orang lain. Hanya Allah yang berhak menghakimi orang lain sebab Dia adalah raja bagi kita semua. LouwNida Lexicon menegaskan,

Penghakiman ialah untuk memutuskan pertanyaan tentang benar atau salah secara hukum, dan dengan demikian menentukan tidak bersalah atau bersalahnya terdakwa dan menetapkan hukuman atau retribusi yang sesuai untuk memutuskan pertanyaan hukum, bertindak sebagai hakim, membuat keputusan hukum, untuk sampai pada putusan, untuk mengadili suatu kasus dalam bentuk pasif untuk diadili. ${ }^{9}$

Allah adalah hakim yang menentukan benar dan salahnya setiap manusia. Dialah yang memiliki kuasa untuk menghakimi setiap orang yang melakukan kesalahan bukan manusia sebab semua manusia di dunia ini berdosa. Jadi, jika seseorang berani menghakimi orang lain dan menentukan hukuman bagi orang lain sama artinya sedang membawa diri sendiri kepada penghakiman Allah.

Penghakiman tanpa belas kasihan artinya hukuman tanpa pengampunan. Kenapa tanpa pengampunan? Karena tidak memiliki belas kasihan yang artinya tidak mau

${ }^{5}$ N. T. Wright, "The New Perspective on Paul (2003)" Dalam Pauline Persepective: Essays on Paul, 1978-2013 (Minneapolis: Fortress, 2013)” (n.d.): 281.

6 Oecumenius "On James 2:13 - Catena Bible \& Commentaries," accessed October 18, 2021, https://catenabible.com

${ }^{7}$ Ibid.

8 "Unforgiveness by Hagin Kenneth (z-Lib," n.d., 19.

${ }^{9}$ Louw-Nida Lexicon, Bible Works, n.d. 
mengampuni orang lain. Karena itu, pada saat penghakiman dia juga tidak mendapatkan pengampunan. "Jika kamu tidak mengampuni orang, Bapamu juga tidak akan mengampuni kamu" (Mat. 6:15). Lebih lanjut, Matius 16:19 berkata, "Kepadamu akan Kuberikan kunci kerajaan Sorga. Apa yang kamu ikat di dunia ini akan terikat di sorga dan apa yang kamu lepaskan di dunia ini akan terlepas di sorga." ini menunjukkan ukuran yang seseorang pakai untuk mengukur orang lain akan dipakaikan kepadanya. ${ }^{10}$ Agustinus dari Hippo menegaskan, "Dia yang menghakimi tanpa belas kasihan akan dihakimi tanpa belas kasihan. Dan dalam pengertian ini hanya "ukuran yang sama" yang harus dipahami, bahwa belas kasihan yang tidak akan ditunjukkan kepadanya, dan penghakiman yang dia buat akan abadi, meskipun hal yang dinilai tidak mungkin abadi."11 Ukuran yang dipakai untuk penghakiman adalah ukuran yang kita kerjakan selama kita hidup, karena ukuran yang sedang dikerjakan bersifat abadi.

Hukuman yang diterima karena tidak memiliki belas kasihan adalah hukuman tanpa kelonggaran. Matthew Poole menegaskan di dalam tafsirannya bahwa hukuman tanpa belas kasihan adalah "shall be judged according to the rigour of the law, by pure justice without any mixture of mercy," sebab orang yang tidak menunjukkan belas kasihan adalah "that hath been cruel and unmercifully to his neighbour here." 12 Ini berarti setiap orang akan menerima pengadilan dan hukuman sesuai dengan apa yang telah ia perbuat tanpa ada belas kasihan. Menerima penghakiman tanpa belas kasihan berarti relasi dengan sesama tidak baik, karena tidak ada belas kasihan, cara untuk memperbaiki relasi tersebut melalui pengampunan (mengampuni orang yang bersalah) Mat. 6:14. Agustine menegaskan bahwa pengampunan tidak bisa diabaikan sebab ini adalah perintah Tuhan dan Dia ingin setiap manusia berbelas kasih supaya jauh dari penderitaan. ${ }^{13}$ Sebab relasi yang baik antara sesama dan juga Tuhan akan terpelihara dengan menuruti firman-Nya dan memberi pengampunan tanpa batas. Luput dari penghakiman berarti relasi dengan sesama dilandaskan dengan belas kasihan, karena itu dia juga menerima belas kasihan dari Allah. Ini menunjukkan bahwa Allah sangat menekankan betapa pentingnya belas kasihan itu. John chrysostom menegaskan,

Belas kasih adalah seni tertinggi dan perisai bagi mereka yang mempraktikkannya. Itu adalah sahabat Tuhan, selalu berdiri di sampingnya dan dengan bebas memberkati apapun yang dia inginkan. Itu tidak boleh dibenci oleh kita. Karena dalam kemurniannya, ia memberikan kebebasan besar kepada mereka yang menanggapinya dengan cara yang sama. Itu harus ditunjukkan kepada mereka yang telah bertengkar dengan kita, juga kepada mereka yang telah berdosa terhadap seseorang, begitu besar kekuatannya. ${ }^{14}$

Orang yang memiliki belas kasihan adalah orang yang bersahabat dengan sesama dan Tuhan. Dengan belas kasihan yang ia miliki ia tidak dibenci oleh sesama dan Allah melainkan dikasihi. Jadi, belas kasihan adalah kunci baik buruknya relasi kita dengan sesama dan juga kepada Allah.

\footnotetext{
${ }^{10}$ A.A Sitompul, Sinopsis Ketiga Injil (Jakarta: Lembaga Alkitab Indonesia, 1993), 116.

11 Augustine of Hippo, dikutip dalam "George Leo Haydock on John 1:14 - Catena Bible \& Commentaries."

12 Matthew Poole, A Commentary on the Holy Bible: Matthew-Revelation, 886.

13 Augustine of Hippo, "('Mastthew 6-Catena Bible \& Comentaris,' Accessed July 31, 2021, Https://Catenabible. Com/Mt/6.)."

${ }_{14}$ John Chrysostom, "On James 2:13 - Catena Bible \& Commentaries," accessed June 16, 2021, https://catenabible.com/com/5879d137dd1bb6dd3dba9ee8.
} 
Penghakiman tanpa belas kasihan yang dimaksud adalah penghakiman Allah yang terakhir. Pada hari terakhir ketika Allah menghakimi, Dia tidak akan menunjukkan belas kasihan "pertaining to the lack of mercy or the refusal to be merciful - 'merciless, unmercifu. ${ }^{15}$ Kata tersebut mengacu pada tindakan yang tidak berbelas kasih. Di sini Yakobus ingin menjelaskan bahwa jika seseorang tidak berbelas kasihan, maka ia akan menerima penghakiman yang sama.

Kata 'belas kasihan' muncul sebanyak dua kali dalam surat Yakobus, yaitu: “Sebab Allah tidak akan menunjukkan belas kasihan kepada orang yang tidak mengenal belas kasihan. Tetapi belas kasihan lebih kuat daripada hukuman!" (Yak. 2:13 BIS) dan "Tetapi orang yang mempunyai kebijaksanaan yang berasal dari atas, ia pertama-tama sekali murni, kemudian suka berdamai, peramah, dan penurut. Ia penuh dengan belas kasihan dan menghasilkan perbuatan-perbuatan yang baik. Ia tidak memihak dan tidak berpurapura" (Yak. 3:17 BIS). Dari kedua ayat ini dapat dilihat bahwa Yakobus mengaitkan belas kasihan dengan penghakiman dan juga hikmat yang dari Allah. Hal ini menunjukkan bahwa orang yang memiliki hikmat dari Allah memiliki sikap belas kasihan. Sebaliknya, orang yang tidak menunjukkan belas kasihan tidak memiliki hikmat dari Allah dan pada waktu penghakiman akan dihakimi oleh Allah sesuai dengan perbuatannya.

Kita yang telah menerima belas kasihan Allah, demikian juga sudah seharusnya kita berbelaskasihan kepada orang lain. Chrysostom menegaskan, jika kita mengampuni dosa orang lain yang telah mereka lakukan terhadap kita dan memberikan sedekah kepada orang miskin dan membutuhkan di antara kita, maka belas kasihan Tuhan akan membebaskan kita dari penghakiman. Tetapi jika sebaliknya, kita tidak berwatak baik terhadap orang-orang di sekitar kita, kita akan menerima hukuman yang diberikan kepada hamba yang jahat itu, bersama dengan pembalasan yang disebutkan dalam Doa Bapa Kami. Karena di sana kami meminta Tuhan untuk mengampuni kami seperti kami mengampuni orang yang bersalah kepada kami, (Mat 6:12) tetapi jika kami tidak mengampuni mereka, kami juga tidak akan diampuni.

Jhon Crysostom dalam komentarinya ini menyatakan dengan jelas bahwa setiap orang yang penuh belas kasihan tidak akan sulit mengampuni orang yang menyakiti, dalam hal ini memberikan pengampunan supaya diri sendiri akan memperoleh belas kasihan dan pengampunan dari Allah. Sebab tanpa belas kasihan maka pengampunan akan sulit ditunjukkan kepada orang lain. Mereka yang memberi pengampunan dalam belas kasihan memudahkan diri sendiri untuk menuju hidup kekekalan bersama dengan Tuhan. Yohanes Sekundar menegaskan bahwa mengampuni sesama supaya mendapat pengampunan dari Bapa. Dalam doa Bapa kami yang diajarkan oleh Yesus ada ungkapan: "Ampunilah kami akan kesalahan kami, seperti kami juga mengampuni orang yang bersalah kepada kami" (Mat. 6:12). ${ }^{16}$

Jadi, hal ini menyadarkan semua orang percaya yang sangat sulit memberikan pengampunan kepada sesama, kitapun harusnya ingat bahwa kita juga orang yang berdosa yang membutuhkan pengampunan dari Bapa. Dalam doa Bapa kami di sini Matius menyampaikan kepada semua orang percaya untuk meneladani Tuhan Yesus yang selalu memberikan pengampunan tanpa batas. Jika tidak memberikan pengampunan maka akan mengalami konsekuensi dari Allah yaitu penghakiman akhir.

15 Louw-Nida Lexicon, Bible Works.

16 Yohanes Sukendar et al., "Pengampunan Menurut Kitab Suci Perjanjian Baru," SAPA-Jurnal Kateketik dan Pastoral 2, no. 2 (2017): 27. 
Penghakiman dari Allah berlaku kepada orang yang menyia-nyiakan belas kasihan dari Allah, yaitu mereka yang tidak membagikan belas kasihan yang diberikan Allah kepadanya. Jadi, belas kasihan kepada orang lain adalah kunci atau penentu apakah kita menerima penghakiman dari Allah.

Setiap manusia harus memiliki belas kasihan kepada sesama. Clement of Alexandria menyatakan bahwa sebagai anak-anak Tuhan harus berbelas kasihan kepada sesama, termasuk memberikan pengampunan kepada orang yang menyakiti, jangan menghakimi melainkan berbelas kasihan kepada mereka yang membenci, dalam hal memberikan pengampunan agar diri sendiri akan memperoleh belas kasihan dan dosa kita pun di ampuni oleh Allah. ${ }^{17}$ Itulah alasan sebagai orang percaya harus berbelas kasihan karena hidup dengan penuh belas kasihan maka ia tidak akan sulit untuk mengampuni dan hidupnya jauh dari pertikaian.

Hendi menuliskan bahwa belas kasihan Tuhan itu ialah kesabaran yang tak terhingga, tak terbatas, dan terus memberi kesempatan kepada manusia sampai menghasilkan yang baik.18 Belas kasihan Tuhan yang tak terbatas ini akhirnya tidak mendatangkan murka dan penghukuman melainkan memberi pengampunan. Tanpa belas kasihan seseorang kepada orang lain, maka orang itu pun tidak memperoleh belas kasihan dari Allah. Dengan belas kasihan seseorang kepada orang lain, Allah sendiri akan membalasnya dengan memberikan berbelas kasihan pada saat penghakiman sehingga tidak binasa melainkan memperoleh keselamatan atau bebas dari penghakiman akhir.

Sebagai orang percaya, harus meneladani kerahiman Allah dimana dalam belas kasih-Nya menyatakan pengampunan-Nya kepada umat manusia. Inilah yang dikatakan Paulus di dalam Efesus 4:32 bahwa, "Hendaklah kamu ramah seorang terhadap yang lain, penuh kasih mesra dan saling mengampuni, sebagaimana Allah di dalam Kristus telah mengampuni kamu." Dalam hal ini Paulus mengajak pengikut Kristus untuk mengambil bagian dalam menyalurkan kasih-Nya dengan cara memberi pengampunan bagi sesama sebagai bukti bahwa mereka telah menerima pengampunan dari Tuhan oleh karena belaskasih-Nya. John Chrysostom berpendapat bahwa mengampuni itu berguna untuk kebaikan jiwa kita dan juga sekaligus sebagai tindakan kebajikan bagi yang menerima pengampunan. ${ }^{19}$ Jadi, ketika memberi pengampunan kehidupan akan terus dibaharui sehingga menjadi sama seperti hati Kristus yang berbelas kasih untuk kepada setiap manusia.

William Barclay menyimpulkan perkataan Yakobus "belas kasihan menang atas penghakiman" artinya pada hari penghakiman akan ada orang-orang yang akan menang dari penghakiman karena dalam diri mereka telah menerapkan belas kasihan. ${ }^{20}$ Jadi, orang yang memiliki belas kasihan adalah orang yang bebas dari penghakiman Allah dan beroleh pembebasan dari Allah sebab mereka telah mengasihi orang lain. Allah sendiri yang mengatakan jika seseorang menghakimi sesama, maka Allah juga akan menghakimi seseorang dan jika membebaskan (mengasihi) sesama kita maka Allah juga mengasihi kita (Mat. 7:2).

17 Clemen of Alexandria, “'Luke 6:36-Catena Bible\&Comentaris,'accessed Agustus 162021://Catenabible.Com/Mt/6."

18 Hendi, "('Belas Kasihan Tuhan Sarkic, Noetic, Psychic, Anagogic Reader - Wordpress.Com,' Accessed July 31, 2021, Http://Wordpress.Com/Read/Blog/17281495/Posts/5682)."

19 John Chrysostom, "(Ephesians 4-Catena Bible \& Commentaries," Accessed July 31, 2021, Https://Catenabible.Com/Eph/4).”

${ }^{20}$ William Barclay, Pemahaman Alkitab Setiap Hari Surat Yakobus 1\&2 Petrus ( Jakarta:2002), 113.' 


\section{Belas Kasihan Menang Atas Penghakiman}

Belas kasihan adalah suatu tindakan mengampuni orang yang bersalah. Oecumenis menegaskan bahwa jika mau mengampuni orang yang berdosa, maka belas kasihan Tuhan akan membebaskan manusia dari penghakiman. ${ }^{21}$ Ini berarti mengampuni orang sama dengan membebaskan diri sendiri dan mendapatkan belas kasihan dari Allah (Mat. 6:15). Hendi menegaskan bahwa mengampuni orang lain berarti sedang meminta Tuhan untuk mengampuni dosa sendiri (Mat. 6:12; 5:17). ${ }^{22}$ Allah telah memberikan teladan yang paling utama dalam mengampuni dan seharusnya semua orang percaya mengampuni sama seperti Dia. Di sini orang percaya mengajak orang lain untuk melihat Allah yang penuh kasih. Herry mengatakan bahwa pengampunan adalah aspek penting yang tidak bisa dipisahkan dari kehidupan orang percaya. ${ }^{23}$ Kebanyakan orang mengaku ia adalah orang percaya tetapi sulit untuk memberi pengampunan yang penuh hati bagi sesamanya.

Tuhan mengajarkan setiap manusia memiliki hati yang mau mengampuni. Mengapa? Karena manusia lebih dahulu menerima pengampunan dari Allah. Pengampunan yang manusia terima adalah pengampunan yang seutuhnya berasal dari Allah (pengampunan dari dosa). Ini artinya pengampunan tersebut yang membebaska manusia. Namun, masih banyak manusia termasuk orang percaya menyalah gunakan pengampunan yang Allah berikan, mereka hanya fokus pada pengampunan saja tetapi tidak mengerti bahwa di balik pengampunan tersebut ada belas kasihan atau anugerah Allah di dalamnya. Sukendar mengatakan bahwa pengampunan selalu berhubungan erat dengan kematian Kristus di kayu salib dimana darah-Nya tercurah untuk menanggung dosa kita yang berarti ada pengampunan atau pembebasan atas setiap dosa. ${ }^{24}$

Surip Stanislaus menjelaskan bahwa mengampuni berarti membawa, mengangkat, atau menanggung. ${ }^{25}$ Ini artinya bahwa dosa ditanggungkan melalui penyaliban Yesus. Namun dalam tulisannya Herry lebih menyoroti bahwa pengampunan itu ada karena belas kasihan Allah kepada manusia, untuk itu manusia khususnya orang percaya di harapkan memiliki belaskasihan dalam hidupnya dan menggunakan belas kasihan itu sebagai alat untuk menyalurkan cinta kasih Tuhan bagi setiap orang percaya ataupun orang yang belum percaya kepada Yesus Kristus. ${ }^{26}$ Oleh sebab itu pengampunan yang diberikan oleh Tuhan melalui belas kasih dan pengorbanan-Nya menjadi acuan setiap orang percaya untuk mengampuni sama seperti Tuhan yang telah memberi pengampunan tanpa batas kepada semua manusia. Maka Allah memberikan pengampunan kepada orang yang mau mengampuni orang lain. Jadi, mengampuni orang lain adalah kunci memperoleh pengampunan dari Allah (Mat. 6:14).

Bukti orang percaya memiliki belas kasihan adalah mengampuni. Mengampuni orang lain berarti diri sendiri sedang memperbaiki hubungan dengan Allah dan sesama. Ketika orang lain melakukan kesalahan dan tidak mau mengampuni berarti relasi dengan Dia sedang terputus. Ketika relasi dengan sesama terputus berarti relasi dengan Tuhan juga terputus, karena tidak mungkin bisa mengasihi Allah yang tidak kelihatan

\footnotetext{
21 Oecumenius, "On James 2:13 - Catena Bible \& Commentaries.”

${ }^{22}$ Hendi, Inspirasi Kalbu 3 (Yogyakarta: Leutika Prio, 2019), 108.

23 Herry Jeuke Nofrie Korengkeng, “Konsep Pengampunan Menurut Matius 18:21-35 Dan Implikasinya Bagi Gereja Masa Kini'” 1 no. 2 (2020): 1.

24 Sekundar, "Pengampunan Menurut Kitab Suci Perjanjian Baru," n.d., 1.

25 Surip Stanislaus And Arie R. Oktavianus Saragih, "'BELAS KASIH \& KEADILAN ALLAH (Kel 34:57),' Logos" 17, no. 2 (2020): 9.

26 Herry Jeuke Nofrie Korengkeng, “'Konsep Pengampunan Menurut Matius 18:21-35 Dan Implikasinya Bagi Gereja Masa Kini,"' 1.
} 
jika sesama yang kelihatan saja tidak kasihi. Untuk memulihkan kembali relasi itu diri sendiri dituntut harus mengampuni, sebab relasi dengan sesama manusia menentukan relasi kepada Allah (1 Yoh. 4:20-21). Jika relasi dengan sesama terputus berarti relasi dengan Allah juga sedang terputus.

Mengampuni orang lain berarti menang atas penghakiman. Menang dari penghakiman berarti bebas dari penghakiman Allah. Chrysostom menegaskan bahwa orang yang mau mengampuni adalah orang yang dibebaskan dari kegelapan api yang tidak pernah padam, bebas dari kertakan gigi (Mar. 9:44-48). ${ }^{27}$ Ini menunjukkan bahwa mengampuni menentukan kehidupan seseorang di hari penghakiman Allah. Di saat orang percaya tidak mau membebaskan orang lain dari kesalahannya berarti orang tersebut sedang membiarkan diri sendiri dihakimi oleh Allah. Jadi, penghakiman yang diberikan Allah tergantung diri sendiri dan relasi dengan sesama.

Setiap orang percaya yang tidak ingin mengampuni, diapun tidak akan menerima pengampunan baginya sendiri sekalipun mengaku sebagai orang yang percaya Yesus. Di dalam Matius 6:14-15 dikatakan, "Karena jikalau kamu mengampuni kesalahan orang, Bapamu yang disorga akan mengampui kamu juga. Tetapi jikalau kamu tidak mengampuni orang, Bapamu juga tidak akan mengampuni kesalahanmu." Tanpa mengampuni terlebih dahulu maka pengampunan dari Bapa tidak akan diterimanya. Sebab memberi pengampunan kepada orang lain adalah sebagai ciri dan tanggungjawab setiap orang percaya. Karnia menuliskan bahwa apa yang dipratekkan seseorang sebenarnya merupakan manifestasi dari keyakinannya. ${ }^{28}$ Mengimani Allah yang telah mengampuni semestinya akan mendorong manusia untuk mengampuni. Ini artinya bahwa pengampunan yang akan di terima dari Bapa yang disorga tergantung bagaimana kita memberi pengampunan kepada orang lain. Ketika tidak dapat memberi pengampunan, maka pengampunan dari Bapa tidak akan kita terima.

George Leo Haydock menegaskan bahwa penghakiman tanpa belas kasihan adalah peringatan bagi mereka yang tidak memiliki belas kasihan. Yesus sendiri mengatakan berbahagialah mereka yang penuh dengan belas kasihan karena mereka akan mendapatkan belas kasihan (Mat. 5:7). ${ }^{29}$ Goldie Bristol mengutip pernyataan David Augsburger menjelaskan bahwa belas kasihan memiliki kekuatan untuk memulihkan keadaan yang sekarang, menyembuhkan yang akan datang dan membebaskan diri dari masa lalu (kesalahan yang telah di lakukan). ${ }^{30}$ Belas kasihan yang ditunjukkan memiliki kemampuan untuk memulihkan hubungan baik dengan masa lalu, masa sekarang, maupun yang akan datang. Hanya orang yang memiliki belas kasihan yang memperoleh kebahagiaan, sebab mereka terbebas dari penghakiman Allah, yaitu hukuman Allah pada penghakiman Akhir.

\section{Implikasi Bagi orang percaya}

Pada masa kini banyak orang percaya yang tidak menyalurkan belas kasihan kepada sesama justru mereka lebih memilih untuk menghakimi, dan tidak mengampuni. Setiap orang percaya telah menerima pengampunan dari belas kasihan Tuhan. Dan belas kasihan itu seharusnya ada di dalam diri setiap kita untuk dapat mengampuni orang lain sama seperti apa yang Tuhan berikan untuk kita semua orang percaya. Orang percaya diperintahkan untuk tidak menghakimi, ini seharusnya menyadarkan setiap orang

27 John Chrysostom, "James 2:13 - Catena Bible \& Commentaries."

28 Karnia Mariana Kawengian, "'Diampuni Untuk Mengampuni Sebagai Pendampingan Pastoral Kepada Anggota Jemaat DI GMIM Efata Tompaso' Education Christ.” 1 (2), 220 (2020): 2.

29 George Leo Haydock, "George Leo Haydock on James 2:13 - Catena Bible \& Commentaries."

${ }^{30}$ Goldie Bristol, Perumpamaan-Perumpamaan Tuhan Yesus (Surabaya, 1983), 166. 
percaya belajar dari pribadi Paulus yang kemudian sadar bahwa menghakimi bukanlah wewenang dari pada dirinya. Paulus jauh di dalam hatinya tahu bahwa penghakiman tidak bisa dilakukan jika belum waktunya, waktu disini tentunya menunjuk pada waktu Tuhan. Penghakiman akan terjadi pada saat kedatangan Yesus yang kedua kalinya. Ia akan menerangi kegelapan dimana kejahatan yang selama ini mungkin saja tersembunyi sampai tidak dapat dihakimi dan semua orang akan melihat dengan trasnparan hal-hal yang perlu dihakimi oleh Allah (1 Kor. 5:12; 4:5).

Yang harus dilakukan setiap orang percaya yang sudah menerima belas kasihan dari Allah adalah memiliki hati yang tulus untuk dapat memaafkan terlebih dahulu agar pengampunan dapat dilepaskan untuk sesama. Semangat pengampunan seharusnya menjadi bagian dari pada kehidupan kerohanian kita, Aphrahat the Persia mengatakan betapa indahnya doa dan betapa bersinarnya karya-karyanya. Doa diterima oleh Allah ketika disertai dengan perbuatan baik, dan didengar ketika muncul dari semangat pengampunan. Doa selalu dijawab ketika itu murni dan tulus.

Jadi sebagai orang yang sudah menerima belas kasihan Tuhan seharusnya membersihkan hati yang masih kotor akan dosa dendam karena tidak mau melepaskan pengampunan dan masih memiliki hati yang selalu inggin menghakimi sesama dengan tolak ukur keadilan. Allah adalah Allah yang adil. Jadi disini jelas bahwa apapun yang dilakukan akan dikembalikan sangat adil kepada kita. Orang yang menabur sedikit, akan menuai sedikit juga, dan orang yang menabur banyak akan menuai juga banyak (2 Kor. 9:6). Jadi sebagai orang percaya yang telah menerima belas kasihan dari Tuhan dan pengampunan sudah seharusnya menyalurkan belas kasihan tanpa batas dan mengajak orang lain untuk melihat Allah yang penuh kasih.

\section{Kesimpulan}

Belas kasihan merupakan hal yang penting dan menjadi pusat dari kehidupan manusia. Belas kasihan dinyatakan melalui perbuatan kita selama di dunia. Apabila belas kasihan tidak diterapkan maka menimbulkan penghakiman dari Allah. oleh sebab itu manusia mebutuhkan belas kasihan dari Allah. manusia yang telah memperoleh belas kasihan dari Allah harus menyalurkan belas kasihan itu kepada sesamanya. Setiap orang Kristen seharusnya sadar akan pentingnya belas kasihan. Bukan hanya orang miskin yang membutuhkan belas kasihan, tetapi semua orang membutuhkannya. Kesadaran akan hal inilah yang mengingatkan kita untuk memiliki belas kasihan terhadap sesama. Bukti kita memiliki belas kasihan adalah dengan mengampuni orang yang bersalah terhadap kita. Dengan belas kasihan seseorang kepada orang lain, Allah sendiri akan membalasnya dengan memberikan belas kasihan pada saat penghakiman sehingga tidak binasa melainkan memperoleh keselamatan atau bebas dari penghakiman akhir.. Karena dengan mengerjakan belas kasihan kita pun akan mendapatkan belas kasihan dari Allah. Sebaliknya jika kita tidak memiliki belas kasihan kita pun tidak akan mendapatkan belaskasihan.

Pada saat penghakiman orang yang memiliki belas kasihan akan mendapatkan belas kasihan dari AllAh dan orang yang tidak memiliki belas kasihan terhadap sesamanya dan tersebutakan mendaptkanpenghakiman dari Allah. Belas kasihan merupakan sumber dari pengampunan untuk memperoleh belas kasihan kita harus meminta belas kasihan tersebut dari Allah yang adalah sumber dari belas kasihanBelas kasihan inilah yang membebaskan dan memenangkan setiap orang percaya dari penghakiman Allah. Jadi seluruh artikel ini berusaha untuk menunjukkan bahwa belas 
kasihan adalah kunci untuk menang dari penghakiman Allah serta mengajak semua orang percaya untuk memiliki belas kasihan.

\section{Referensi}

A.A Sitompul. Sinopsis Ketiga Injil. Jakarta: Lembaga Alkitab Indonesia, 1993.

Augustine of Hippo. '('Mastthew 6-Catena Bible \& Comentaris,' Accessed July 31, 2021, Https://Catenabible. Com/Mt/6.)."

Clemen of Alexandria. "'Luke 6:36-Catena Bible\&Comentaris,'accessed Agustus 162021://Catenabible.Com/Mt/6."

George Leo Haydock. "George Leo Haydock on James 2:13 - Catena Bible \& Commentaries."

Goldie Bristol. Perumpamaan-Perumpamaan Tuhan Yesus. Surabaya, 1983.

Hendi. "('Belas Kasihan Tuhan Sarkic, Noetic, Psychic, Anagogic Reader Wordpress.Com,' Accessed July 31, 2021, Http://Wordpress.Com/Read/Blog/17281495/Posts/5682)."

——_. Inspirasi Kalbu 3. Yogyakarta: Leutika Prio, 2019, n.d.

Herry Jeuke Nofrie Korengkeng. "'Konsep Pengampunan Menurut Matius 18:21-35 Dan Implikasinya Bagi Gereja Masa Kini”" 1 no. 2 (2020).

John Chrysostom. "(Ephesians 4-Catena Bible \& Commentaries," Accessed July 31, 2021, Https://Catenabible.Com/Eph/4)."

-_—. "James 2:13 - Catena Bible \& Commentaries."

- - C. "On James 2:13 - Catena Bible \& Commentaries." Accessed June 16, 2021. https://catenabible.com/com/5879d137dd1bb6dd3dba9ee8.

Karnia Mariana Kawengian. "'Diampuni Untuk Mengampuni Sebagai Pendampingan Pastoral Kepada Anggota Jemaat DI GMIM Efata Tompaso' Education Christ." 1 (2), 220 (2020).

Louw-Nida Lexicon. Bible Works, n.d.

Matthew Henry. Tafsiran Matthew Henry:Surat Ibrani, Yakobus, 1\&2 Petrus, 1-3 Yohanes, Yudas Dan Kitab Wahyu. Surabaya, 2016.

N. T. Wright. "The New Perspective on Paul (2003)" Dalam Pauline Persepective: Essays on Paul, 1978-2013 (Minneapolis: Fortress, 2013)" (n.d.).

Oecumenius. "On James 2:13 - Catena Bible \& Commentaries." Accessed June 16, 2021. https://catenabible.com/com/5879d137dd1bb6dd3dba9ef8.

Sekundar. "Pengampunan Menurut Kitab Suci Perjanjian Baru," n.d.

Surip Stanislaus And Arie R. Oktavianus Saragih. "BELAS KASIH \& KEADILAN ALLAH (Kel 34:5-7),' Logos" 17, no. 2 (2020).

William Barclay. Pemahaman Alkitab Setiap Hari Surat Yakobus 1\&2 Petrus. Jakarta., 2002.

William Dyrnes. "'Mercy Triumphs Over Justice: James 2:13 and the Theology of Faith and Works - The Gospel Coalition,' Accessed June 16, 2021, Https://Www.Thegospelcoalition.Org/Themelios/Article/Mercy-Triumphs-overJustice-James-213-and-the-Theology-of-Faith-and-Works/."

"Churchofjesuschrist.Org."

"George Leo Haydock on John 1:14 - Catena Bible \& Commentaries." 